Ciência e Natura, Santa Maria v.39 n.3, 2017, Set - Dez, p. 627 - 634

Revista do Centro de Ciências Naturais e Exatas - UFSM

ISSN impressa: 0100-8307 ISSN on-line: 2179-460X

\title{
CIÊNCIANATURA
}

\section{Space-time distribution of rainfall anomaly index (RAI) for the Salgado Basin, Ceará State - Brazil}

\author{
Juliana Alcântara Costa e Gláuber Pontes Rodrigues \\ Universidade Federal do Ceará \\ juliana-alcantara-costa@gmail.com; pontesglauber@gmail.com
}

\begin{abstract}
Given the great variability of the precipitation in the Brazilian Northeast, it is necessary to use climate indexes for its monitoring. In this sense, this work aims to present a study of the space-time variation in the rainfall at the Salgado Basin, located in the state of Ceará, using the Rainfall Anomaly Index (RAI) as a tool. In order to do so, daily precipitation data from seven meteorological stations were used for the period between 1974 and 2015. From the data obtained, the RAI was calculated and plotted in spatial distribution maps. It was possible to observe that the rainy season at the basin lasts from January to April, and the driest period of the year lasts from July to October. The historical series presented drier years than rainy ones. A variation in the RAI within the basin was evidenced, and the region corresponding to Chapada do Araripe was wetter. The years with the extreme anomalies were related to sea surface temperature anomaly events, which favored its occurrence.
\end{abstract}

Keywords: Climatic indexes. Drought. SSTA. 


\section{Introduction}

In the Brazilian Northeast (BNE), rainfall is the result of the behave between several atmospheric systems that behave at various scales and periodicity regimes (ARAÚJO; MORAES NETO; SOUSA, 2009). Some examples are the Frontal Systems (KOUSKY, 1979), the Upper Tropospheric Cyclonic Vortices (KOUSKY; GAN, 1981), the Intertropical Convergence Zone (ITCZ) and the Eastern Waves (FERREIRA; MELLO, 2005).

In addition, pioneer studies accomplished by Walker (1928) already indicated that the anomalous warming of surface waters in the equatorial Pacific exerts influence on the BNE droughts. Since then, several studies have been carried out, also presenting evidence of the role played by the Atlantic and the Pacific Oceans in the climate fluctuations in South America (ANDREOLI, KAYANO, 2007; SILVA et al., 2011).

Therefore, based on the irregularity and seasonality of rainfall, monitoring by means of the use of climatic indexes is necessary. Based on this, it is possible to develop a monitoring system of the characteristics of dry and rainy periods (DA SILVA et al., 2009).

Santos, Araújo and Marcelino (2015) emphasize the importance of developing and encouraging regional policies that seek to reduce adverse effects on hydrological systems. The authors state that the prior knowledge about the climatic characteristics of the area in issue by means of effective monitoring is essential.

In light of this context, the Rainfall Anomaly Index (RAI), developed by Rooy (1965), is used to classify the positive and negative severities in rainfall anomalies. It is considered an index of remarkable procedural simplicity because it requires only precipitation data (Freitas, 2005; Fernandes et al., 2009). According to Rooy (1965), RAI aims to make the comparison between precipitation deviations in different regions feasible.

Araújo, Morais Neto and Sousa (2009), with the objective of analyzing the climatology of the Paraíba river basin, used RAI as a tool and found similarities in the precipitation pattern between the regions from the basin.

Sanches, Verdum and Fisch (2014) used the RAI with the goal of analyzing the annual precipitation variability from 1928 to 2009 in Alegrete/RS, as well as comparing the indices obtained from El Niño Southern Oscillation events (ENSO) and Pacific Decadal Oscillation (PDO). The authors concluded that RAI presented itself as an important tool in the analysis of precipitation in the municipality.

Santos, Araújo and Marcelino (2015) utilized RAI under the Mamanguape river basin / PB, obtaining its climatic analysis and concluding, among other things, that the basin has three regions with different precipitation patterns.

Therefore, this work aimed at presenting a study of the space-time variation of the rainfall precipitation in the Salgado river basin, in the state of Ceará, utilizing the Rainfall Anomaly Index (RAI) as a tool, as well as accomplishing its spatial distribution in order to identify areas of higher or lower severity of events.

\section{Material and methods}

The present study was developed for the Salgado River Basin (Figure 1). It is located in the southern region of the state of Ceará and it has the Salgado River, a tributary of the Jaguaribe River, as the main river, with $308 \mathrm{~km}$ of length. In addition, it drainage area of $12,623.89 \mathrm{~km}^{2}$, which is equivalent to $9 \%$ of the state territory, encompassing 23 municipalities (CEARÁ, 2009). 
The database used in this study was obtained by means of 7 meteorological stations of the Meteorology Foundation in Ceará - FUNCEME, provided by the National Water Agency (ANA), by means of the Hidroweb platform (http://hidroweb.ana.gov.br). Data from the daily precipitation of the period between 1974 and 2015 (42 years) at the stations located in Aurora, Crato, Icó, Jardim, Mauriti, Milagres and Várzea Alegre were utilized.

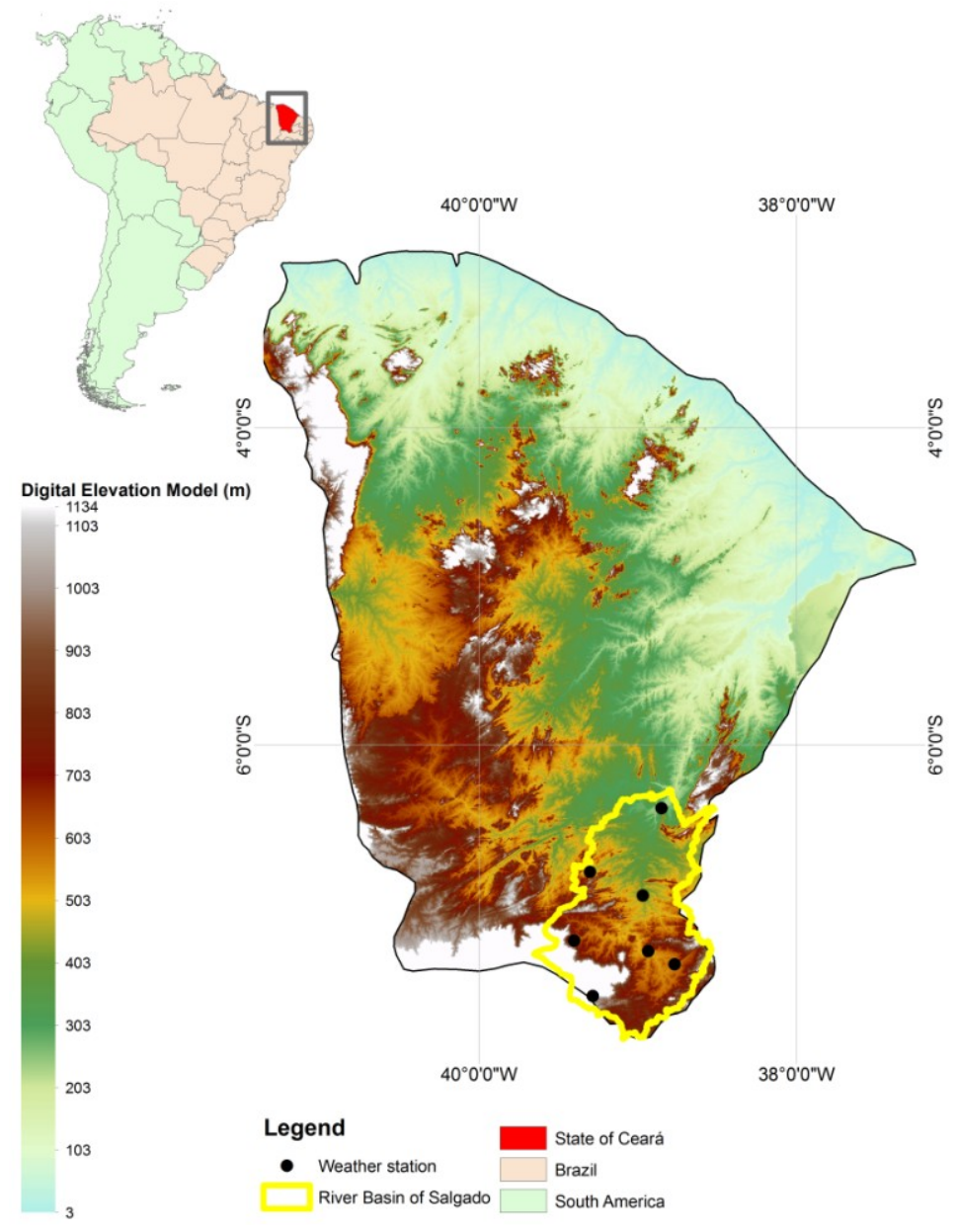

Figure 1 - Salgado River Basin with the location of the stations used

From the precipitation data, the Annual Rainfall Anomaly Index (RAI) was calculated to analyze the frequency and intensity of the dry and rainy years in the studied area. In addition, the monthly RAI was calculated for specific years of the historical series aiming to analyze the distribution of rainfall in the years of greatest anomaly.

RAI, developed and firstly used by Rooy (1965) and adapted by Freitas (2005), constitutes the following equations:

$\mathrm{RAI}=3\left[\frac{\mathrm{N}-\mathrm{N}}{\overline{\mathrm{M}}-\mathrm{N}}\right]$, For positive anomalies

RAI $=-3\left[\frac{N-N}{\bar{X}-\mathrm{N}}\right]$, For negative anomalies 
Where: $\mathrm{N}=$ current monthly/yearly rainfall, in order words, of the month/year when RAI will be generated (mm); $\overline{\mathrm{N}}=$ monthly/yearly average rainfall of the historical series (mm); $\overline{\mathrm{M}}=$ average of the ten highest monthly/yearly precipitations of the historical series $(\mathrm{mm}) ; \overline{\mathrm{X}}=$ average of the ten lowest monthly/ yearly precipitations of the historical series $(\mathrm{mm})$; and positive anomalies have their values above average and negative anomalies have their values below average.

Table 1 - Classification of Rainfall Anomaly Index Intensity

\begin{tabular}{c|c|c}
\hline & RAI range & Classification \\
\hline \multirow{4}{*}{$\begin{array}{c}\text { Rainfall Anomaly } \\
\text { Index (RAI) }\end{array}$} & Above 4 & Extremely humid \\
\cline { 2 - 3 } & 2 to 4 & Very humid \\
\cline { 2 - 3 } & 0 to 2 & Humid \\
\cline { 2 - 3 } & -2 to 0 & Dry \\
\cline { 2 - 3 } & -4 to -2 & Very dry \\
\hline
\end{tabular}

Source: Freitas (2005) adapted by Araújo et al. (2009)

The result was plotted in a spatial distribution map in the Surfer ${ }^{\circledR}$ 13.0 Software, utilizing the Kriging method.

\section{Results and discussion}

From the temporal spatial distribution of rainfall in the Salgado river basin shown in Figure 2, it is possible to perceive that the rainy season begins in the month of January and lasts until the month of April. Within this range, the precipitation is higher than the annual average (approximately $74 \mathrm{~mm}$ ). The month of March presented the highest precipitation value, around $206 \mathrm{~mm}$, corroborating Araujo, Morais Neto and Sousa (2009)'s assertion that this month is more efficient in terms of precipitation in the Northeast, because it has a greater influence of the Intertropical Convergence Zone (ITCZ), which is important for the rivers recharge.

The four-month period from July to October showed itself as the driest period of the year, with a minimum precipitation of $3.27 \mathrm{~mm}$, on average, in the month of August.

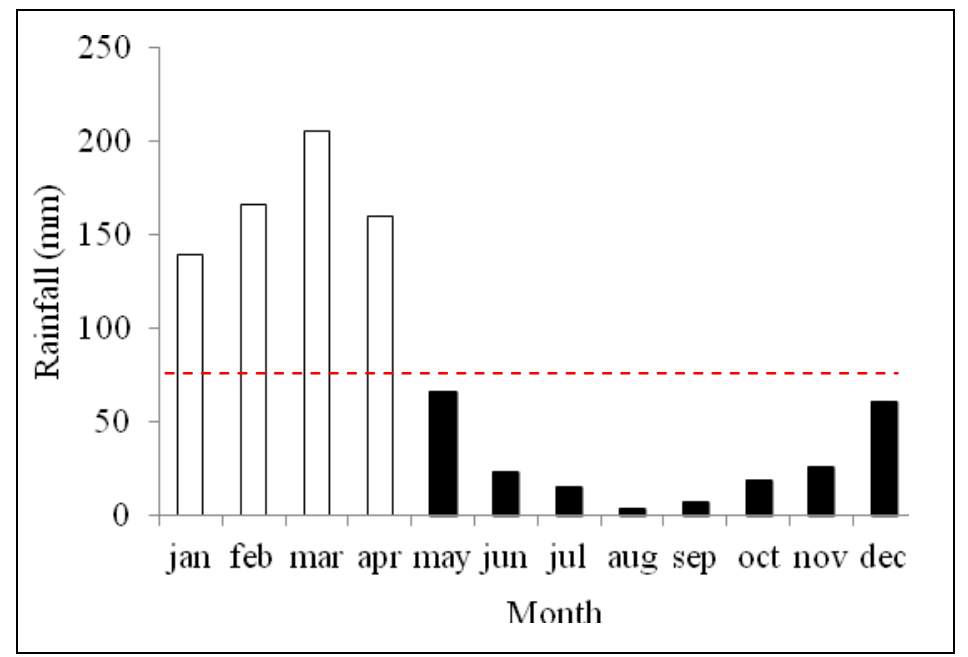

Figure 2 - Climatological averages from 1974 to 2015 of the precipitations for the Salgado Basin 
The drought years and the rainy years, during the period from 1974 to 2015, can be visualized by means of RAI (Figure 3), enabling to identify periods where these events were more intense and/or lasting.

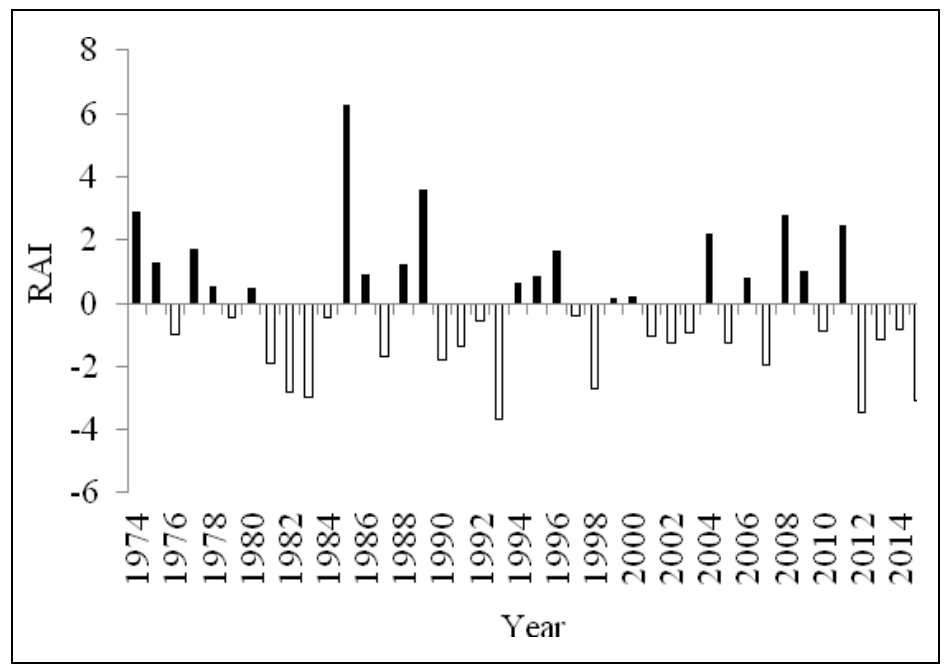

Figure 3 - Rainfall Anomaly Index for the Salgado Basin

The positive values observed in Figure 3 represent rainy or wet years and the negative values represent the dry years, with different degrees of intensity. The occurrence of 19 years with a positive RAI, varying from extremely wet to humid, and 23 years with a negative RAI, varying between very dry and dry was observed. In other words, there were more years of drought than rainy ones.

The periods that remained the longest with droughts were from 1981 to 1984, from 1990 to 1993, and from 2012 to 2015 (Figure 3). 1993 was the year with the highest negative value, with a RAI of -3.69, classified as very dry. The year of greatest positive value was 1985, with an average RAI of 6.29, being therefore classified as extremely humid. Araújo, Morais Neto and Sousa (2009) and Da Silva et al. (2009) found similar results for the Paraíba river basin.

Concerning the occurrence of drought and rainy years, Santos, Araújo and Marcelino (2015) affirm that the reduction in the interval between consecutive dry years interspersed by a rainy year favors the water supply of the basin, as is the case of the period from 2004 to 2011.

Figure 4 shows the spatial distribution of the RAI across the territory of the Salgado River Basin. It is also possible to observe that the average RAI for the period was negative for the entire area. A range of 0.27 in the RAI variation within the basin was also observed, with a clear division in the spatial distribution of precipitation in the hydrographic basin, since the northeast portion presented a lower RAI than in the southwest. The wettest part corresponds to the region under the influence of Chapada do Araripe, which is a region of denser vegetation. This condition provides greater evapotranspiration and higher altitude and, consequently, it is predictive for the formation of orographic rainfall.

In order to better evaluate the distribution of rainfall in the Salgado river basin in the years of more extreme anomalies, the monthly RAI of specific years were analyzed (Figure 5). The two most humid indexes (1985 and 1989) and the two driest ones (1993 and 2012) of the historical series were chosen. 


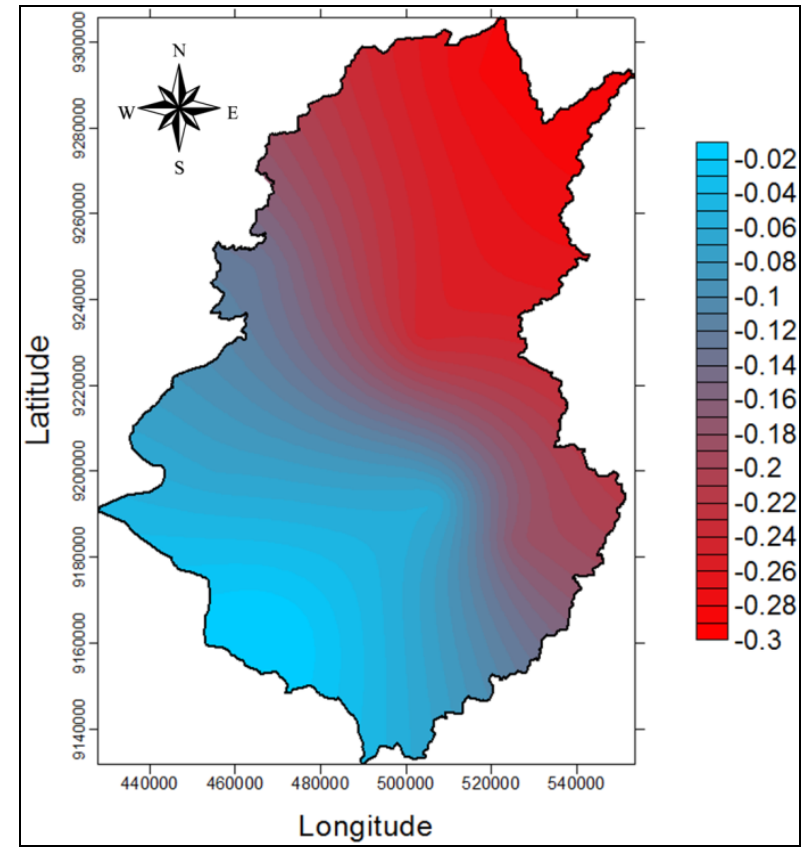

Figure 4 - Spatial distribution of the rainfall anomaly index in the Salgado River Basin
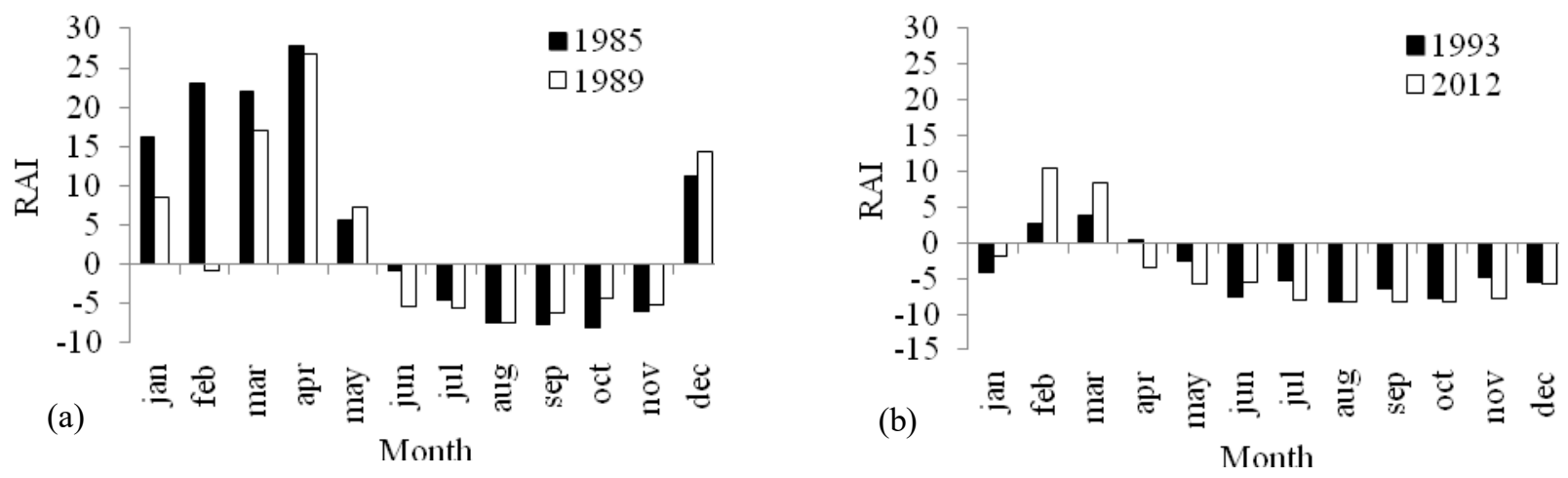

Figure 5 - Monthly RAI of the Salgado River Basin: rainy years (a) and dry years (b)

It was possible to observe in Figure 5a that the years of 1985 and 1989 presented a similar distribution of rainfall throughout the year, except for the month of February, where the year of 1989 presented a slightly negative RAI, differing from 1985 and from the climatological average presented in Figure 2.

The driest years in the historical series (Figure 5b) presented precipitation above average only in the months of February and March. The month of April also presented RAI classified as rainy, but only for the year of 2012. In light of this context, it is possible to infer that in very dry years, even in the rainy season, there are months when RAI tends to be negative, as observed by Araújo, Morais Neto and Sousa (2009), Da Silva et al. (2009) and Santos, Araújo and Marcelino (2015).

In order to analyze RAI spatially within the Salgado river basin in the years of more extreme anomalies, Figure 6 was elaborated. It is possible to visualize that in in the year of 1985 (Figure 6a) RAI was positive throughout the territorial extension of the basin. According to Brabo Alves (2012), such fact can be explained because this year was 
under the influence of two Sea Surface Temperature Anomaly (SSTA) events - namely La Niña and the Atlantic Dipole Negative - which favor the occurrence of precipitation in the Northeast of Brazil, ANDREOLI, KAYANO, 2007).

The most extreme negative anomaly value in the Salgado river basin appeared in 1993 (Figure 6b). That year, according to Nóbrega and Santiago (2014), was El Niño strongest year. This phenomenon is responsible for the scarcity of rainfall in the NEB (ANDREOLI, KAYANO, 2007). Thus, it is observed that the IAC in 1993 was negative in the entire area of the basin, corroborating with Nóbrega and Santiago (2014) that observed that in 1993 the state of Pernambuco also presented strong drought due to El Niño.
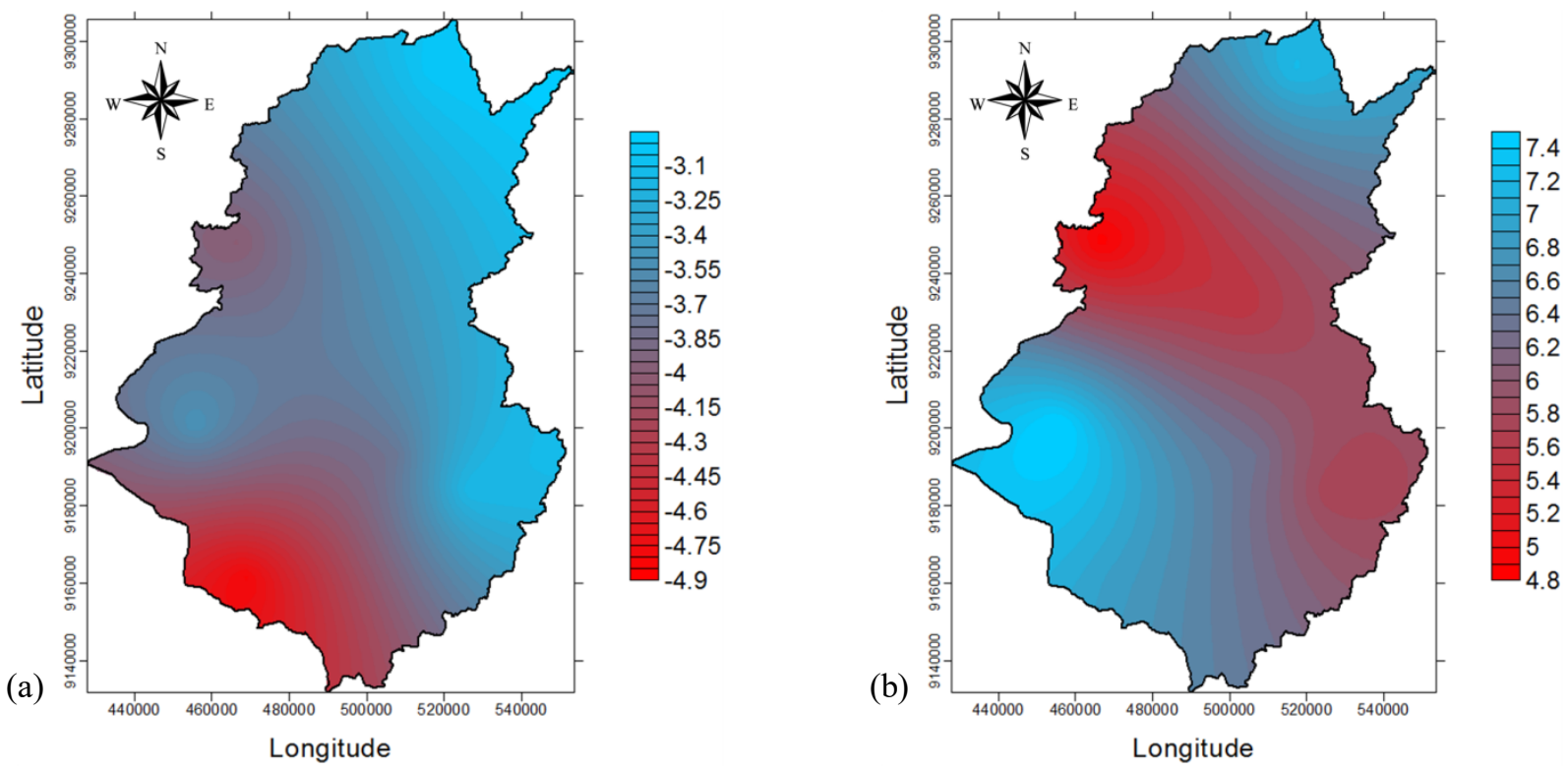

Figure 6 - Spatialization of RAI in the most extreme years: 1985 (a) and 1993 (b)

\section{Conclusions}

The rainy season of the Salgado river basin extends from January to April and the driest period of the year lasts from July to October.

The historical series presented 19 rainy years and 23 dry years, with 1985 as the wettest year and 1993 as the driest.

An amplitude of 0.27 was observed in the RAI variation within the Basin, and the region corresponding to Chapada do Araripe was more humid in comparison to the northeast of the basin.

The dry years present a negative anomaly even in the months of the rainy season at the basin.

Influences of the Sea Surface Temperature Anomalies in the Pacific and Atlantic under the basin were confirmed, since the extreme RAI years were related to phases of these events that favored their occurrences. 


\section{Referências}

ANDREOLI RV, KAYANO MT. A importância relativa do Atlântico Tropical sul e Pacífico leste na variabilidade de precipitação do nordeste do Brasil. Rev. Bras. Meteorol. 2007; 22(1): 63-74.

ARAÚJO LE, MORAES NETO JM, SOUSA FAS. Classificação da precipitação anual e da quadra chuvosa da bacia do rio paraíba utilizando índice de anomalia de chuva (IAC). Rev. Ambient. Água. 2009; 4(3): 93-110.

BRABO ALVES JM. Recentes variações climáticas no Nordeste do Brasil com ênfase a precipitação: relações com ENOS, Dipolo de temperatura da superfície do Mar no Atlântico Tropical e a Oscilação decadal do Pacífico. Rev. Geogr. 2012; 29(3): 147-166.

CEARÁ. Assembléia Legislativa. Caderno regional da bacia do salgado/Conselho de altos estudos estratégicos. Fortaleza: INESP. 2009; 11. 131 p.

DA SILVA DF, SOUSA FAS, KAYANO MT, GALVÍNCIO JD. Influência da variabilidade climática global e de suas escalas temporais sobre a precipitação no Alto Mundaú (PE). Rev. Bras. Geogr. Fís. 2009; 2, (3): 64-82.

FERREIRA AG, MELLO NGS. Principais Sistemas Atmosféricos Atuantes Sobre a Região Nordeste do Brasil e a Influência dos Oceanos Pacífico e Atlântico no Clima da Região. Rev. Bras. Climatol. 2005; 1(1): 15-28.

FERNANDES DS, HEINEMANN AB, PAZ RL, AMORIM AO, CARDOSO AS. Índices para a Quantificação da Seca. Santo Antônio de Goiás, Embrapa Arroz e Feijão, 2009.

FREITAS MAS. Um sistema de suporte à decisão para o monitoramento de secas meteorológicas em regiões semiáridas. Rev. Tecnol. 2005; (suppl 19): p. 84-95.

KOUSKY VE. Frontal influences on northeast Brazil. Mon. Weather Rev. 1979; 107(9): 1140-1153.

KOUSKY VE, GAN MA. Upper tropospheric cyclones vórtices in the tropical South atlantic. Tellus. 1981; 33(6): 538551.

NÓBREGA RS, SANTIAGO GACF. Tendência de temperature na superfície do mar nos oceanos Atlântico e Pacífico e variabilidae de precipitação em Pernambuco. Mercator. 2014; 13(1): 107-118.

ROOY MP. van. A Rainfall Anomaly Index Independent of Time and Space. Notos. 1965; 14, 43p.

SANTOS ECA, ARAÚJO LE, MARCELINO AS. Análise climática da Bacia Hidrográfica do Rio Mamanguape. Rev. Bras. Eng. Agríc. Ambient. 2015; 19(1): 9-14.

SANCHES FO, VERDUM R, FISCH GO Índice de Anomalia de Chuva (IAC) na avaliação das precipitações anuais em Alegrete/RS (1928-2009). Cam. Geogr. 2014; 15(51): 73-84.

SILVA APNS, MOURA GBA, GIONGO PR, MEDEIROS SRR. Correlação entre as Temperaturas da Superfície do Mar e a quantidade da precipitação na estação chuvosa no Nordeste do estado de Pernambuco. Rev. Bras. Meteorol. 2011; 26(1): 149-156.

WALKER GT. Ceará (Brazil) famines and the general air movement. Beitr. Phys. d. freien Atm, 1928; 14: 88-93. 